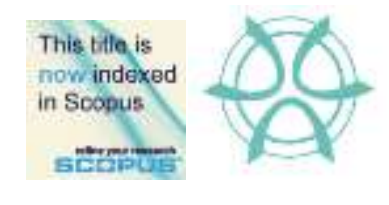

PLANNING MALAYSIA:

Journal of the Malaysian Institute of Planners

VOLUME 19 ISSUE 1 (2021), Page 162 - 173

\title{
ASSESSING MRT FEEDER BUS SERVICES PERFORMANCE THROUGH PASSENGER'S SATISFACTION LEVEL IN THE SELECTED STATIONS OF KLANG VALLEY, MALAYSIA
}

\section{Oladejo Aliu Olabayonle ${ }^{1}$, Muhammad Rijal Mohamad ${ }^{2}$, Syahriah Bachok ${ }^{3}$ and Mohammad Zarif Mohd Zahari ${ }^{4}$}

\author{
Kulliyyah of Architecture and Environmental Design (KAED) \\ INTERNATIONAL ISLAMIC UNIVERSITY MALAYSIA (IIUM) \\ Department of Built Environment and Technology Studies, \\ UNIVERSITI TEKNOLOGI MARA, SERI ISKANDAR BRANCH
}

\begin{abstract}
Resultant impacts of mobility increase within the Klang Valley, for example, congestion, parking problem and air pollution have highlighted the reason for a move towards the use of more sustainable transport modes within the cities. Hence the need for effective and reliable public transport. It is perceived that Mass Rapid Transit (MRT) feeder buses hold the guarantee of easing the growing congestion in Klang Valley if they are managed efficiently and sustainably. For this reason, this research expands the exploration of the MRT feeder bus services quality by evaluating the passengers' level of satisfaction. A quantitative approach was employed for this study by administration of the questionnaire. A total of 303 survey forms were collected through convenience sampling. The study's findings confirmed the efficiency and effectiveness of services provision. Surveys showed that most riders $(62.7 \%)$ were females with the majority possessing a bachelor's degree and above (64.4\%). Also, a large proportion of the riders fell into the age group category between 20 and 29 years $(69.0 \%)$, with less than half of the respondents earning an average monthly income of above RM 6,000 (45.9\%). Most of the respondents were satisfied with the overall quality (above $80 \%$ satisfactory) but punctuality, waiting and travel times as well as services frequency of this first and last mile connection (FLM) had left a lot to be desired. The study also found significant relationships between gender and the fear of crime as well as conditions of bus stops. Thus, it recommends overall enhancement of service with safer environment for female riders and an increase in the service frequency of the MRT feeder buses to retain the existing users and attract more new users.
\end{abstract}

Keywords: MRT Feeder Bus, Service quality, Passenger Satisfaction, Fairness

\footnotetext{
${ }^{1} \mathrm{PhD}$ Student at International Islamic University Malaysia. Email: haliyy_4luv@yahoo.com
} 


\section{INTRODUCTION}

As each country's population keeps growing, the public transportation need is very high to serve all human beings moving from one location to another. In the past two decades, the number of private car dependency has highly increased as it is the most favourable mode adopted by many people across the globe, including Klang Valley, in Malaysia (Shaharudin et al., 2018).

The private car enables people to gain services and maintain social relationships more quickly than the other modes. However, cities depending on this mode of transport would be continuous and prolonged congestion. Cities with conventional bus services have, in turn, failed to convey many people to land uses where activities are carried out because of the limited bus service capacity. Today, the city centres' major roads are nearing their usage capacity, and the Klang Valley's land scarcity issue is no longer suitable for more road development and parking facilities. Evidence of this can be seen in most places within the cities whereby many roads were fully crowded with cars parked up to the point of double and triple parking, which added more to the road congestion (Shaharudin et al., 2018). Traffic congestion within the city is increasing, and as a result, it takes even longer to arrive at one's destination (Chuen et al., 2014).

Within the Klang Valley, limited parking space, traffic congestion and environmental pollution have become significant concerns, particularly with the high growth of motorisation in the region (Almselati, 2011). Also, the productive time lost during the congestion will eventually cost the nation its competitiveness, particularly in its critical economic corridor. The situation is becoming worrisome in Klang Valley while comparing higher public transport usage in cities like Singapore, Hong Kong and London, where travels using public transportation being above $60 \%$ and nearly reaching $90 \%$ (Chuen, 2014).

Hence, first and last-mile (FLM) complimentary public transport such as feeder bus is essential as one of the significant elements for the country's growth, specifically in the city centre where a high density of development filled with people dominate the central core area. The chairman of the Commission of Public and Land Transport emphasised that only 5\% of Malaysians opted for public transportation to travel nationwide (Dahalan et al., 2017), meaning that, compared to private vehicles, fewer people are using public transport (Borhan et al., 2019; Ismail et al., 2012).

Thus, this study aimed at assessing the current MRT feeder bus services in selected stations of Klang Valley, Malaysia and offered a possible framework for efficient and sustainable feeder bus service. The study achieved this by determining the satisfaction level among the riders in the ten selected stations and analysing the factors influencing individual satisfaction level. 
Oladejo Aliu Olabayonle1, Muhammad Rijal Mohamad2, Syahriah Bachok3, and Mohammad Zarif Mohd Zahari Assessing MRT Feeder Bus Services Performance Through Passenger's Satisfaction Level in the Selected Stations of Klang Valley Malaysia

\section{LITERATURE REVIEW}

A transit mode must be competitive against other available transit modes for a given trip so that rider might choose the given mode as depicted in the manual (Transportation Research Board, 2002, p. 5). Areas of concerns to the travellers when deciding to ride the public transport include public transport service availability and whether the available service is convenient and comfortable. Some of the factors influencing the passengers' choices are under the transit agency's control, such as travel time, safety and security, service delivery, and maintenance. The entirety of the above-referenced, except for safety and security, relates directly to service reliability. Service deliveries mirror the daily basis aspects of how well the service meets the passengers' expectations, for example, how well the actual service corresponds to the scheduling. Likewise, the travel times and how well the actual travel times fit the timetable, just as if the travel times are planned so that the trip length is reasonable and competitive to other available modes. Service reliability on an incident basis could be put under the maintenance part, for example, if a vehicle breaks down during the service and how the transit agency manages the situation. Passenger satisfaction is a cornerstone in running a successful public transport system. The number of riders has to be sufficient for the system to be effective and economical. As recently portrayed, service reliability is connected to the passengers' reflections severally and consequently the most critical factor in passenger satisfaction (Transportation Research Board, 2013). Additionally, FLM connection is the main factor contributing to the successes of suburban and outskirt stations (Feinsod et al., 2016), where demand catchment radius tended to be wider (Guerra \& Cervero, 2013). Bus-based FLM faces longer travel time especially when trapped in congestion due to the road-sharing nature of the services.

Rojo et al. (2015); Chocholac (2020), and Zakiah et al. (2017) argue passengers' satisfaction survey is a vital tool to measure the efficiency and effectiveness of any bus services which could also serve as a benchmark or an indicator for enhancing any bus service delivery efficiency and effectiveness. Similarly, Ismail et al. (2012) defines passengers' satisfaction survey as a judgement by the riders relating to the pleasant level of consumption.

Ismail et al. (2012) assert that bus quality of service and riders' level of satisfaction, prominent features are measurable by the levels of the convenience of the bus, reliability of the bus, bus condition, degree of difficulties (ingress and egress), safety and security, service information, travel time, and service frequency. Service quality lies around intangibility, heterogeneity and inseparability (Mikhaylov et al., 2015) and can be characterised as the degree and direction of disparity between the perception of passenger and passenger expectations (Morton et al., 2016). Although there is no particular specification to quantify the quality of service rendered by the bus, the attributes in passengers' 
satisfaction study are considered as adequate as far as the service quality evaluation is concerned (Ismail et al., 2012). For a new system such as the MRT feeder services, which began in 2017 , following the commencement of the rail system operation, it is essential to record the longitudinal progression of such quality. Focus on safety and security are presented in this study, as contemporary literature has also concentrated on equality and fairness issues (Hail \& McQuaid, 2021; Rock et al., 2014). Whilst females travel greater distances to more varied destinations and have greater access to diversified transportation mode; public transportation design and services have been centred around a typically maledominated environment (Priya Uteng \& Turner, 2019; Peters, 2013), especially in developing cities, including Klang Valley. Hence, aspects of gender and safety and gender and convenience/comfort are discussed in this study.

\section{METHODOLOGY}

This present study adopted a quantitative approach. The data was acquired through a personally administered survey which otherwise known as a selfadministered questionnaire, the most common tool to assess passengers' perception. Survey forms were distributed using convenience sampling at the various MRT feeder bus stations in the Klang Valley. The most crowded MRT stations (based on observational counts in a pilot survey) were selected for the study as the sampling frame. Due to a large population (Shaharudin et al., 2018) for the overall MRT feeder bus stations, some 380 riders were targeted as the sample size. However, out of 380 questionnaires distributed, only 303 (79.7\%) were valid and further analysed. The remaining forms happened to be filled by those waiting at the bus stops but were non-users of the feeder bus; hence, those people were not eligible to represent the study population. The dependent variable employed in this study was the overall passengers' satisfaction with the service provided by the MRT feeder bus, categorised by the specific service quality characteristics that comprise comfort and convenience, reliability and vehicle conditions, among others service qualities. Independent variables are the sociodemographic and trip characteristics of the respondents. The data were analysed using IBM Statistical Package for Social (SPSS) software, version 24, to present the descriptive findings, such as the frequency analysis and the cross-tabulation of variables.

\section{FINDINGS AND DISCUSSION Demographics}

The passengers' demographics were analysed. Table 2, presented gender, age group, education level, income and occupational status distributions. Table 2 shows that $62.7 \%$, were female users. This result was comparable to the gender distribution of developed nations such as the United States of American (Clark, 
Oladejo Aliu Olabayonle1, Muhammad Rijal Mohamad2, Syahriah Bachok3, and Mohammad Zarif Mohd Zahari Assessing MRT Feeder Bus Services Performance Through Passenger's Satisfaction Level in the Selected Stations of Klang Valley Malaysia

2017). Some $62.7 \%$ fall into the most economically active age ranging from 20 to 29 years old. The rest were divided between the age group between 30 and 39 years (12.5\%), below 20 years (12.5) and the remainder being 40 years or older $(6.0 \%)$. Likewise, more than average riders were either bachelor's degree holders or higher $(64.4 \%)$, while the rest were either school or college certificate holders $(35.6 \%)$.

Table 2: Demographic Factors of the Passengers

\begin{tabular}{|c|c|c|}
\hline Demographic Factors & Frequency & $(\%)$ \\
\hline \multicolumn{3}{|l|}{ Gender } \\
\hline Male & 113 & 37.3 \\
\hline Female & 190 & 62.7 \\
\hline \multicolumn{3}{|l|}{ Age Group } \\
\hline Below 20 & 38 & 12.5 \\
\hline $20-29$ & 209 & 69.0 \\
\hline $30-39$ & 38 & 12.5 \\
\hline Above 40 & 18 & 6.0 \\
\hline \multicolumn{3}{|l|}{ Education } \\
\hline School/College & 108 & 35.6 \\
\hline Bachelor Degree \& Higher & 195 & 64.4 \\
\hline \multicolumn{3}{|l|}{ Income Group } \\
\hline Below 2000 & 50 & 16.5 \\
\hline $2000-3999$ & 48 & 15.8 \\
\hline $4000-5999$ & 66 & 21.8 \\
\hline Above 6000 & 139 & 45.9 \\
\hline \multicolumn{3}{|l|}{ Occupation } \\
\hline School/College/University & 148 & 48.8 \\
\hline Private Sector & 133 & 43.9 \\
\hline Public Sector & 14 & 4.6 \\
\hline Pensioner/Retiree & 2 & 0.7 \\
\hline Housewife & 5 & 1.7 \\
\hline Unemployed & 1 & 0.3 \\
\hline
\end{tabular}

Some $45.9 \%$ riders earned average monthly income of above RM6000, $21.8 \%$ earned between RM4,000 and RM5,999, 16.5\% earned below RM2,000 and $15.8 \%$ earned between RM2,000 and RM3,999. At a glance, it can be seen clearly that the high-income people chose not to ride the public transport most probably due to having ownership and access to a private vehicle. Some $48.8 \%$ of the users intercepted were students, $43.9 \%$ were working in a private sector, 
$4.6 \%$ were working in the public sector, $1.7 \%$ were housewives and the remainder $(0.7 \%)$ were retirees.

Table 3 below revealed the passengers' level of satisfaction with the MRT feeder bus service. Most of the respondents were satisfied with the service of the MRT feeder bus services in all the factors measuring the influence on satisfaction levels. These included bus convenience level, the reliability of the bus, bus physical condition, driver behaviour or attitude, degree of difficulties in ingress and egress and bus stops assessment. The results might have been attributable to respondents being captive to buses as many falls in the category of the low-income earners (Table 2) and the MRT feeder bus service being a newly installed infrastructure. According to many studies conducted in Malaysia (Shaharrudin et al., 2018; Chuen et al., 2014; Almselati, 2011; Borhan et al., 2019; Ismail, 2012; and Abdul Jalil et al., 2015), revealed a continuous increase of the private car dependency by the citizens particularly in Klang Valley. When compared to the developed nations such as Singapore and Australia, feeder bus services in Malaysia still needed to improve in many areas, such as the frequency of service, cleanliness and comfort while waiting for the bus at the bus station (see Figure 2a through 2e), hours of service and the reliability of service, among others, to retain the existing users and to capture the attention of the high-income earners.

Worthy of attention is the quality of bus reliability such as departure and arrival times, travel time and services frequency receiving higher dissatisfactory responses $(32.0 \%$ to $35.4 \%)$ compared to variables of other bus quality in the assessment. In Klang Valley, bus-based FLM shared the road space with other users and the former were very susceptible to congestion, incidents and accidents, resulting in unreliability, delay and longer overall travel time. This raised a concern over the effectiveness MRT stations which catchment depended on road-based FLM. A strong feeder is needed to support the rail system to ensure the success of Transit Oriented Development implementation. In the long run, low quality FLM services would not be able to commensurate the more efficient rail-based MRT system, which would jeopardise the hub and spoke system and targeted modal split of 40:60 Klang Valley. Improvement of the feeder system is, therefore, essential to realise various transportation objectives in the city.

Table 3: Passengers Level of Satisfaction with the MRT Feeder Bus Service

\begin{tabular}{|l|c|c|c|c|}
\hline \multirow{2}{*}{ Element } & \multicolumn{4}{|c|}{ Scale of Measurement } \\
\cline { 2 - 5 } & $\begin{array}{c}\text { Very } \\
\text { Dissatisfied } \\
\%\end{array}$ & $\begin{array}{c}\text { Dissatisfied } \\
\%\end{array}$ & $\begin{array}{c}\text { Satisfied } \\
\%\end{array}$ & $\begin{array}{c}\text { Very } \\
\text { Satisfied } \\
\%\end{array}$ \\
\hline \multicolumn{5}{|l|}{} \\
\hline Bus Convenience & 1.0 & 8.3 & 58.1 & 32.7 \\
\hline Information and guidance & 1.0 & 4.6 & 57.4 & 37.0 \\
\hline Ease of boarding or alighting bus & 3.0 & 5.9 & 58.7 & 32.3 \\
\hline
\end{tabular}


Oladejo Aliu Olabayonle1, Muhammad Rijal Mohamad2, Syahriah Bachok3, and Mohammad Zarif Mohd Zahari Assessing MRT Feeder Bus Services Performance Through Passenger's Satisfaction Level in the Selected Stations of Klang Valley Malaysia

\begin{tabular}{|c|c|c|c|c|}
\hline Seat Comfort & 2.0 & 7.3 & 61.1 & 29.7 \\
\hline Crowdedness & 3.0 & 6.6 & 60.4 & 30.0 \\
\hline Air Conditioning & 1.7 & 4.0 & 59.4 & 35.0 \\
\hline Cleanliness & 2.6 & 5.3 & 58.1 & 34.0 \\
\hline Physical Condition & 1.3 & 4.0 & 61.7 & 33.0 \\
\hline Other Bus Users Behaviour & 1.0 & 6.6 & 60.4 & 32.0 \\
\hline Vehicle Breakdown & 1.3 & 4.3 & 58.7 & 35.6 \\
\hline \multicolumn{5}{|l|}{ Reliability of the Bus } \\
\hline Bus arrives on time & 8.9 & 26.4 & 48.8 & 15.8 \\
\hline Bus departs on time & 11.2 & 22.8 & 50.5 & 15.5 \\
\hline Travel Time & 8.3 & 24.1 & 54.5 & 13.2 \\
\hline Service Frequency & 5.6 & 26.4 & 49.5 & 18.5 \\
\hline Safety while onboard & 0.7 & 9.9 & 64.0 & 25.4 \\
\hline \multicolumn{5}{|l|}{ Bus Condition } \\
\hline Appearance of the Bus & 1.0 & 5.0 & 44.9 & 49.2 \\
\hline Storage Availability in the Bus & 1.3 & 7.6 & 42.9 & 48.2 \\
\hline Provision and Visibility of Handrails & 1.0 & 3.6 & 49.2 & 46.2 \\
\hline Shape or diameter of Handrails & 0.7 & 5.0 & 62.4 & 32.0 \\
\hline $\begin{array}{l}\text { Passenger Injured due to the } \\
\text { Handrails }\end{array}$ & 1.0 & 5.3 & 60.1 & 33.7 \\
\hline Bus Spaciousness & 1.0 & 5.0 & 45.2 & 48.8 \\
\hline \multicolumn{5}{|l|}{ Driver Behaviour/Attitude } \\
\hline Physical Appearance of the Driver & 0.7 & 6.3 & 63.0 & 30.0 \\
\hline Helpfulness of the Driver & 1.3 & 8.6 & 58.1 & 32.0 \\
\hline Improper Bus Parking & 1.3 & 4.6 & 65.3 & 28.7 \\
\hline \multicolumn{5}{|c|}{ Degree of Difficulties in Ingress and Egress of the Bus Passenger } \\
\hline The gap between kerb and bus is wide & 1.0 & 5.6 & 52.8 & 40.6 \\
\hline Steps are too high or otherwise & 1.0 & 4.6 & 52.5 & 41.9 \\
\hline Kerb Level Vary with the Bus Level & 0.7 & 5.6 & 51.2 & 42.6 \\
\hline Comfort Level of handrails & 1.0 & 3.6 & 50.8 & 44.6 \\
\hline $\begin{array}{lll}\text { Handrail } & \text { Access } & \text { during } \\
\text { Ingress/Egress } & & \\
\end{array}$ & 0.7 & 4.3 & 54.1 & 40.9 \\
\hline Preference mode of Ingress/Egress & 1.0 & 4.3 & 52.8 & 41.9 \\
\hline $\begin{array}{l}\text { Ease of Carrying bags while } \\
\text { Ingress/Egress }\end{array}$ & 0.7 & 4.0 & 53.5 & 41.9 \\
\hline $\begin{array}{l}\text { Possibilities of Stumbling on moving } \\
\text { Buses }\end{array}$ & 1.3 & 5.9 & 50.2 & 42.6 \\
\hline \multicolumn{5}{|l|}{ Bus Stops Assessment } \\
\hline Bus Stop Cleanliness & 0.7 & 7.3 & 51.8 & 40.3 \\
\hline $\begin{array}{l}\text { Information prior to travel, during } \\
\text { and after alighting }\end{array}$ & 1.0 & 7.6 & 53.8 & 37.6 \\
\hline $\begin{array}{l}\begin{array}{l}\text { Bus Stop distance from final } \\
\text { destination }\end{array} \\
\text { dest }\end{array}$ & 1.0 & 5.9 & 53.5 & 39.6 \\
\hline Fear of crime at the bus stop & 1.7 & 6.9 & 53.1 & 38.3 \\
\hline Shelter provision at the bus stop & 1.7 & 5.6 & 53.1 & 39.6 \\
\hline Seat comfort & 2.0 & 5.9 & 53.1 & 38.9 \\
\hline Condition of the bus stop & 1.3 & 5.9 & 52.1 & 40.6 \\
\hline Routes map at the bus stop & 2.0 & 6.9 & 51.8 & 39.3 \\
\hline Distance to the bus stop & 1.3 & 5.0 & 53.5 & 40.3 \\
\hline
\end{tabular}




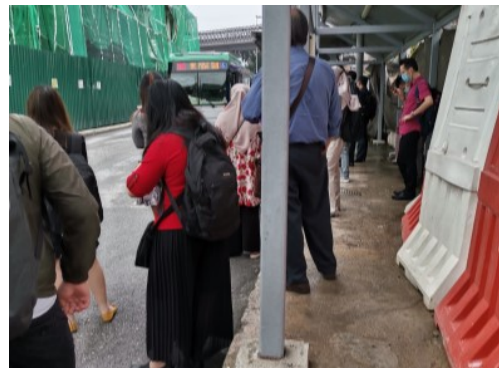

Figure 2a: MRT Feeder Bus Stop at Pusat Bandar Damansara

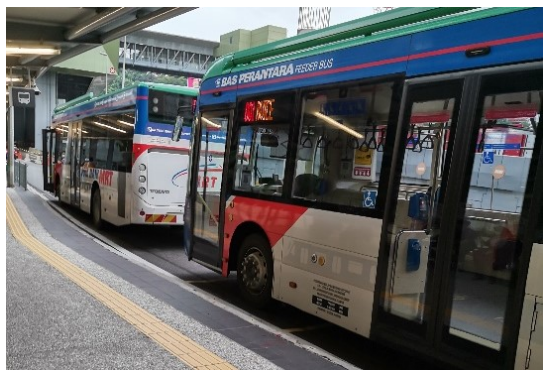

Figure 2b: MRT Feeder Bus Stop at Pusat Bandar Damansara

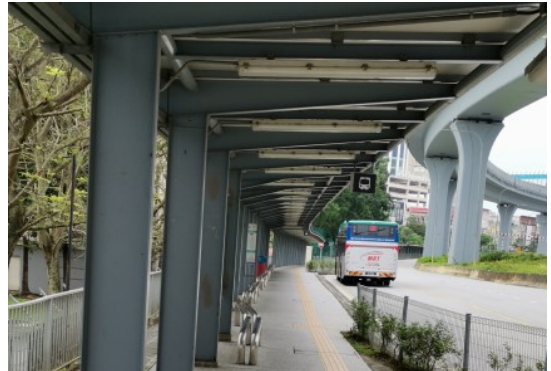

Figure 2c: MRT Feeder Bus Stop at Kota Damansara Pintu B

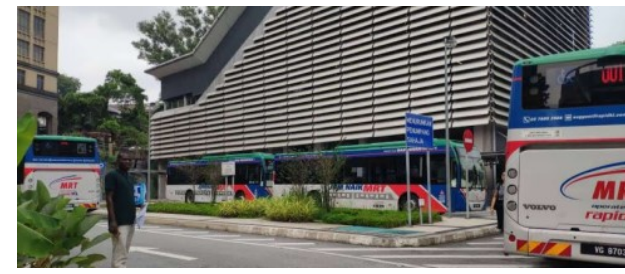

Figure 2d: Riders waiting for the Bus at MRT Feeder Bus Stop at Phileo Damansara

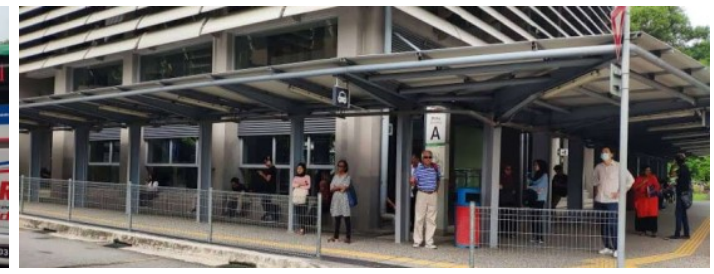

Figure 2e: Riders waiting for the Bus at MRT Feeder Bus Stop at Phileo Damansara

Discussion on gender-specific service provision in public transportation has been on the rise (Ceccato, 2017; Ceccato \& Loukaitou-Sideris, 2020). In assessing this, the study further analysed the bus service quality related to gender-specific issues. Table 4 below shows the relationship between gender and the fear of crime at the respective selected MRT feeder bus station. Only $4.3 \%$ of the female were dissatisfied with the safety at the MRT feeder bus stations. Another $34.0 \%$ and $24.4 \%$ of the female satisfied and very satisfied with their safety. Whereas $1.7 \%$ of their male counterpart were very dissatisfied, $2.6 \%$ dissatisfied, $19.1 \%$ and $13.9 \%$ were satisfied and very satisfied. From this result, it can be deduced that the overall safety concern at the respective bus stations was generally accepted as the majority were satisfied with their respective safety quality. However, indepth statistical tests demonstrated the disparity in perception between the two genders.

\section{Hypotheses Testing}

Various chi-square tests have been carried out on the hypotheses relating to sociodemographics and feeder buses quality perception. Two tests have produced significant results differentiating gender in the perception and of safety and security: fear of crime and bus stops' conditions. Tables below depict the results. 
Oladejo Aliu Olabayonle1, Muhammad Rijal Mohamad2, Syahriah Bachok3, and Mohammad Zarif Mohd Zahari Assessing MRT Feeder Bus Services Performance Through Passenger's Satisfaction Level in the Selected Stations of Klang Valley Malaysia

\section{Hypothesis 1}

$\mathrm{H}_{0}$ : There is no significant relationship between gender and the fear of crime at the MRT feeder bus stops.

$\mathrm{H}_{1}$ : There is a significant relationship between gender and the fear of crime at the MRT feeder bus stops.

Table 4: Gender against Fear of Crime at the Bus Stop

\begin{tabular}{|r|r|r|r|r|r|r|}
\hline \multicolumn{2}{|c|}{ Respondent Gender } & \multicolumn{4}{|c|}{ Fear of crime waiting at the bus stop } & \multirow{2}{*}{} \\
\cline { 3 - 7 } \multicolumn{2}{|c|}{} & $\begin{array}{c}\text { Very } \\
\text { Dissatisfied }\end{array}$ & $\begin{array}{c}\text { Vissatisfied } \\
\text { Satisfied }\end{array}$ & $\begin{array}{c}\text { Very } \\
\text { Satisfied }\end{array}$ & Total \\
\hline Female & Count & 0 & 13 & 103 & 74 & 190 \\
\cline { 2 - 7 } & $\%$ of Total & $0.0 \%$ & $4.3 \%$ & $34.0 \%$ & $24.4 \%$ & $62.7 \%$ \\
\hline Male & Count & 5 & 8 & 58 & 42 & 113 \\
\cline { 2 - 7 } & $\%$ of Total & $1.7 \%$ & $2.6 \%$ & $19.1 \%$ & $13.9 \%$ & $37.3 \%$ \\
\hline
\end{tabular}

Chi-Square Tests

\begin{tabular}{lrrrr} 
& & & & Asymptotic Significance \\
& Value & Df & & (2-sided) \\
\hline Pearson Chi-Square & $8.582^{\mathrm{a}}$ & & 3 & .035 \\
Likelihood Ratio & 10.039 & & 3 & .018 \\
Linear-by-Linear Association & 1.898 & & 1 & .168 \\
N of Valid Cases & 303 & & & \\
\hline
\end{tabular}

The chi-square test showed a $\rho$-value of 0.035 , which was less than 0.05. Therefore, the rejection of the null hypothesis was valid and alternative hypothesis was accepted. In other words, there was a significant relationship between gender and the fear of crime at the MRT feeder bus stops. According to Ceccato (2017), if public transport is not safe, women's mobility is impaired. Though women are most often the target of these behaviours but are not the only victims, it cut across the gender. Many studies have revealed evidence that all gender are often victims of violence and sexual harassment in Portugal (Ceccato, 2017). Hence, it calls for a holistic approach to safety, including understanding the intersectionality of victimisation and fear. Thus, the notion that fear and victimisation are not only influenced by gender but are instead a result of the intersection of an individual's characteristics (Ceccato \& Loukaitou-Sideris, 2020). Several transport systems in Jakarta, New Delhi and even the KTM Komuter system of Klang Valley have segregated facilities for female users such as ladies-only front section of the buses and ladies-only rail coaches.

\section{Hypothesis 2}


$\mathrm{H}_{0}$ : There is no significant relationship between gender and the bus stops condition perception.

$\mathrm{H}_{1}$ : There is a significant relationship between gender and the bus stops condition perception.

Table 5 indicates the relationship between gender and the condition of the bus stop. Out of the total 303 samples, very few of them were dissatisfied with a bus stop condition. Some $3.3 \%$ of females were dissatisfied, while $1.3 \%$ and $2.6 \%$ of the male riders were very dissatisfied and dissatisfied. However, $35.5 \%$ and $24.4 \%$ of the female were satisfied and very satisfied respectively with bus stop conditions. Likewise, $17.2 \%$ and $16.2 \%$ of male riders were too (respectively).

Table 5: Relationship between Gender and Bus Stop Condition

\begin{tabular}{|c|c|c|c|c|c|c|}
\hline \multicolumn{2}{|c|}{ Respondent Gender } & \multicolumn{4}{|c|}{ Bus stop condition } & \multirow[b]{2}{*}{ Total } \\
\hline & & Very Dissatisfied & Dissatisfied & Satisfied & Very Satisfied & \\
\hline \multirow[t]{2}{*}{ Female } & Count & 0 & 10 & 106 & 74 & 190 \\
\hline & $\%$ of Total & $0.0 \%$ & $3.3 \%$ & $35.0 \%$ & $24.4 \%$ & $62.7 \%$ \\
\hline \multirow[t]{2}{*}{ Male } & Count & 4 & 8 & 52 & 49 & 113 \\
\hline & $\%$ of Total & $1.3 \%$ & $2.6 \%$ & $17.2 \%$ & $16.2 \%$ & $37.3 \%$ \\
\hline
\end{tabular}

Chi-Square Tests

\begin{tabular}{lrrrr} 
& & & \multicolumn{2}{c}{$\begin{array}{c}\text { Asymptotic Significance } \\
\text { (2-sided) }\end{array}$} \\
\hline Pearson Chi-Square & $8.757^{\mathrm{a}}$ & & 3 & .033 \\
Likelihood Ratio & 9.934 & 3 & .019 \\
Linear-by-Linear Association & .341 & & 1 & .559 \\
N of Valid Cases & 303 & & & \\
\hline
\end{tabular}

It can be seen from the chi-square test that the $\rho$-value was 0.033 , which was less than 0.05 . Therefore, the null hypothesis was rejected. In other words, there was a significant relationship between gender and the bus stop condition assessment.

The study found that overall perception tended to be positively skewed for a new service system, reflecting the high-quality infrastructure installations in the first few years of operation. At the surface, safety as an overall quality was positively perceived by many users. However, a closer look at user demographics demonstrated otherwise, indicating gender issues like fear of crime and bus stop conditions that still fall below the quality anticipated by females. This significant finding supports various other contemporary research on equality issues (Priya Uteng \& Turner, 2019; Peters, 2013; Duchène, 2011). 
Oladejo Aliu Olabayonle1, Muhammad Rijal Mohamad2, Syahriah Bachok3, and Mohammad Zarif Mohd Zahari Assessing MRT Feeder Bus Services Performance Through Passenger's Satisfaction Level in the Selected Stations of Klang Valley Malaysia

\section{RECOMMENDATION AND CONCLUSION}

In conclusion, this study has identified MRT feeder bus users' level of satisfaction with the current MRT public bus transport system in Klang Valley. The objective of this present research has been achieved by revealing the users' level of satisfaction about services provided by the feeder bus: bus punctuality, frequency of service of the bus, seat availability, waiting time among others and the travel time of the bus, in which needed to be improved to reduce the continuous growing of personal mobility in the core region of Klang Valley. Even though the study has revealed riders were satisfied with the overall services, apart from bus arrival and departure times, overall journey time and bus stop conditions. The reasons for such evaluation can be further investigated in future research opportunity.

This current study is expected to benefit the MRT feeder bus operators in helping to recognise the significant factors that influence the MRT feeder bus users to enhance the services. Having improved the services, especially in FLM travel and waiting times, could increase the number of users, significantly the high- and middleincome people, and ultimately maximise the revenue in the long run. Future research is suggested to include these non-users in their study to ascertain the factors impeding selection to use public transport.

\section{ACKNOWLEDGEMENT}

The authors would like to extend their appreciations to IIUM and Ministry of Higher Education. This research was supported in part by Fundamental Research Grant Scheme, Ministry of Higher Education, Malaysia (FRGS/1/2019/TK08/UIAM/02/1).

\section{REFERENCES}

Almselati, A. S. I., Rahmat, R. A. O. K., \& Jaafar, O. (2011). An overview of urban transport in Malaysia. Social Sci, 6(1), 24-33.

Borhan, M. N., Ibrahim, A. N. H., Syamsunur, D., \& Rahmat, R. A. (2019). Why public bus is a less attractive mode of transport: A case study of Putrajaya, Malaysia. Periodica Polytechnica Transportation Engineering, 47(1), 82-90.

Ceccato, V. (2017). Women's transit safety: Making connections and defining future directions in research and practice. Crime Prevention and Community Safety, 19, 276-287.

Ceccato, V., \& Loukaitou-Sideris, A. (Eds.). (2020). Transit crime and sexual violence in cities: International evidence and prevention. Routledge.

Chiu Chuen, O., Karim, M. R., \& Yusoff, S. (2014). Mode choice between private and public transport in Klang Valley, Malaysia. The Scientific World Journal, 2014.1-14.

Chocholac, J., Sommerauerova, D., Hyrslova, J., Kucera, T., Hruska, R., \& Machalik, S. (2020). Service quality of the urban public transport companies and sustainable city logistics. Open Engineering, 10(1), 86-97. 
Clark, H. M. (2017). Who rides public transportation. http://www.apta.com/resources/reportsandpublications/Documents/APTA-Who-RidesPublic-Transportation-2017.pdf

Dahalan, D., D'Silva, J. L., Abdullah, H., Ismail, I. A., \& Ahmad, N. (2017). Youth confidence in the quality of public transport services: The case of Greater KL, Malaysia. GeografiaMalaysian Journal of Society and Space, 11(9).

Duchène, C. (2011). Gender and transport. International Transport Forum Discussion Papershttp://hdl.handle.net/10419/68812

Feinsod, S., Romo Urroz, E., Haas, P. J., \& Griffith, J. (2016). International Lessons for Promoting Transit Connections to High-Speed Rail Systems.

Guerra, E., \& Cervero, R. (2013). Is a Half-Mile Circle the Right Standard for TODs?

Hail, Y., \& McQuaid, R. (2021). The Concept of Fairness in Relation to Women Transport Users. Sustainability, 13(5), 2919.

Ismail, R., Hafezi, M. H., Nor, R. M., \& Ambak, K. (2012). Passengers preference and satisfaction of public transport in Malaysia. Australian Journal of Basic and Applied Sciences, 6(8), 410-416.

Mikhaylov, A. S., Gumenuk, I. S., \& Mikhaylova, A. A. (2015). The SERVQUAL model in measuring service quality of public transportation: evidence from Russia. Calitatea, 16(144), 78.

Morton, C., Caulfield, B., \& Anable, J. (2016). Customer perceptions of quality of service in public transport: Evidence for bus transit in Scotland. Case Studies on Transport Policy, 4(3), 199-207.

Peters, D. (2013). Gender and Sustainable Urban Mobility. Global Report on Human Settlements. Available from http://www.unhabitat.org/grhs/2013.

Ponrahono, Z., Bachok, S., Osman, M. M., Ibrahim, M., \& Abdullah, M. F. (2017). Public Bus Level of Service Performance in Peninsular Malaysia: Correlation Analyses on Level of Service (LOS) and Passengers Satisfaction Level. Planning Malaysia, 15(1).

Priya Uteng, T., \& Turner, J. (2019). Addressing the linkages between gender and transport in low-and middle-income countries. Sustainability, 11(17), 4555.

Rock, S., Ahern, A., \& Caulfield, B. (2014). Equity and fairness in transport planning: the state of play. In 93rd Annual Meeting of the Transportation Research Board of the National Academies, Washington, $D C$.

Rojo, M., dell'Olio, L., Gonzalo-Orden, H., \& Ibeas, Á. (2015). Inclusion of quality criteria in public bus service contracts in metropolitan areas. Transport Policy, 42, 52-63.

Shaharudin, M. R., Zainoddin, A. I., Akbar, J., Abdullah, D., \& Saifullah, N. H. (2018). Determinants of the Passengers' Light Rail Transit Usage in the Klang Valley Malaysia. Int. J Sup. Chain. Mgt Vol, 7(6), 231.

Transportation Research Board (2013). Part 2 bus transit capacity. In Transit Capacity and Quality of Service Manual Third Edition (pp. 2-1 to 2-96). Retrieved from http://www.trb.org/main/blurbs/169437.aspx

Transportation Research Board. (2002). A guidebook for developing a transit performancemeasurement system transit cooperative research program (Vol. 88). Washington, DC: TransportationResearch Board: United States Federal Transit Administration.

Received: $30^{\text {th }}$ April 2021. Accepted: $4^{\text {th }}$ May 2021 